\title{
Measuring IgG anti-A/B titres using dithiothreitol (DTT)
}

\author{
R. C. KNIGHT
}

From the Department of Haematology, St Thomas's Hospital, London SE1

SUMMARY In comparing the use of the sulphydryl compounds 2-mercaptoethanol (2ME) and dithiothreitol (DTT) a rapid one-stage technique for titrating IgG anti-A and anti-B using DTT in an antiglobulin test was tried. The results correlated well with those obtained by either of the two-stage methods using $2 \mathrm{ME}$ or DTT.

IgG anti-A or anti-B is difficult to demonstrate as its activity is often masked by saline-agglutinating IgM antibodies. In cases of suspected ABO haemolytic disease of the newborn (HDN), however, it is often necessary to titrate the IgG antibody. Many techniques have been described for inactivating IgM antibodies, including the relative thermostability of IgG at $70^{\circ} \mathrm{C}$, differential titres at $20^{\circ} \mathrm{C}$ and $37^{\circ} \mathrm{C}$, and the use of group specific substances from human and animal sources. All these have the disadvantage of either leaving residual IgM activity or inactivating some of the IgG antibodies as well.

Inactivation with 2-mercaptoethanol (2ME) or dithiothreitol (DTT) seems a better technique since IgM not IgG antibodies are inactivated. These sulphydryl compounds dissociate the 19S IgM molecule into $7 \mathrm{~S}$ subunits that do not have antibody activity but leave the IgG molecules intact. Voak and Bowley (1969) showed that the anti-A/B titre determined by a spin antiglobulin technique after $2 \mathrm{ME}$ inactivation correlated well with clinical severity in cases of ABO HDN, a titre of more than 1 in 256 being highly significant.

2ME has the following disadvantages that preclude its widespread use in routine laboratories: (1) the technique is time consuming, especially if dialysis is used; (2) without dialysis false-positive results may occur when using an anti-human globulin (AHG) technique; (3) 2ME has a pungent odour.

DTT does not have these disadvantages since it is odourless, dialysis is not required before AHG techniques, and it is less time consuming. The period of inactivation can be reduced to as short as 15 minutes (Pirofsky and Rosner, 1974). The use of DTT in determining IgG anti-A/B titres is considered in this paper.

Received for publication 27 July 1977

\section{Methods}

2ME was diluted to $0.1 \mathrm{M}$ in phosphate buffered saline $\mathrm{pH} \mathrm{7.4}$. Equal volumes of $2 \mathrm{ME}$ and serum were incubated at $37^{\circ} \mathrm{C}$ for two hours. The treated sera were used without dialysis according to the method of Reesink et al. (1972).

DTT was prepared as 0.01 $\mathrm{M}$ solution in phosphate buffered saline pH 7.4. Aliquots were stored frozen for up to six months and thawed at the time of testing. For the standard technique equal volumes of serum and DTT were incubated at $37^{\circ} \mathrm{C}$ for 30 minutes according to the techniques of Olson $e t$ al. (1976).

For the one-stage technique the serum was diluted 1 in 8 in $0.01 \mathrm{M} \mathrm{DTT}$ and doubling dilutions made in $0.85 \%$ saline. The cells were added without any prior incubation and the tubes incubated at $37^{\circ} \mathrm{C}$ for 30 minutes. The cells were then washed four times in a Sorval cell washer and tested on a tile with commercial AHG and saline.

We use a Technicon BG-10 grouping machine for routine $A B O$ and $R h$ grouping, so in order to select sera for this study samples were also tested with $\mathrm{A}_{1} \mathrm{~B}$ cells at $37^{\circ} \mathrm{C}$ and those showing haemolysis within 30 minutes used. As all sera were tested within 24 hours of collection and only occasionally stored overnight at $4^{\circ} \mathrm{C}$ no additional source of complement was used. Other sera used were those containing antibodies that had been detected in the laboratory during routine testing and stored at $-20^{\circ} \mathrm{C}$ until required.

The broad spectrum AHG was obtained from Biotest Folex Limited and the anti-complement and anti-IgG from the Blood Group Reference Laboratory, London. All were used by a tile technique. Haemagglutination results were scored as in Table 1. 


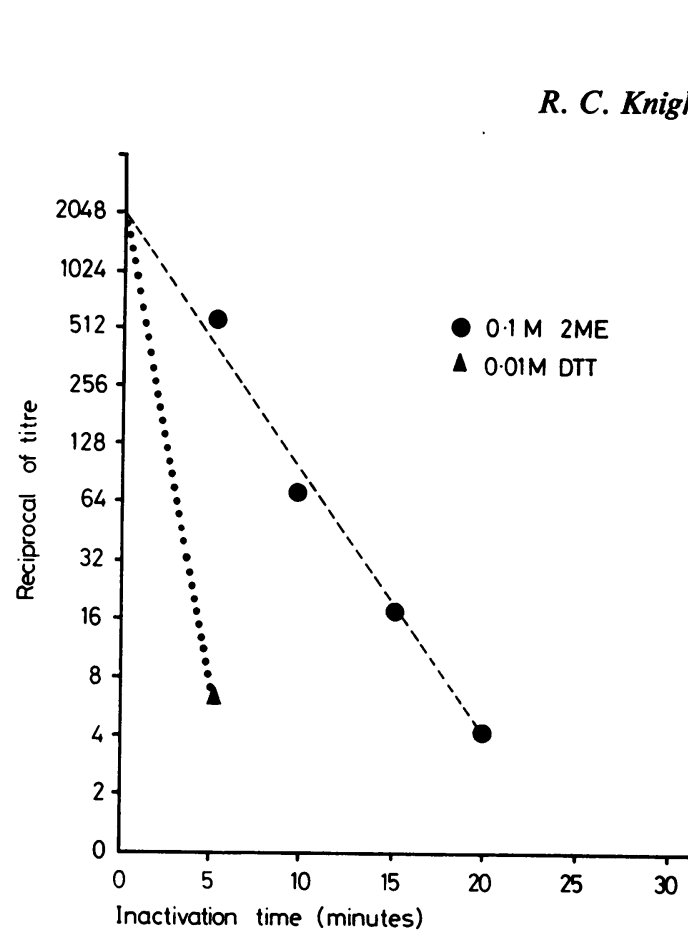

Figure Rate of inactivation at $37^{\circ} \mathrm{C}$ of an IgM anti-I using 0.1 M 2ME and 0.01 M DTT.

were mixed and then diluted serially in $0.85 \%$ saline. One volume of $50 \% \mathrm{~A}_{1} \mathrm{~B}$ cells was added to each dilution and then incubated at $37^{\circ} \mathrm{C}$. The cells were $\stackrel{\varnothing}{\varrho}$ washed four times in saline and then tested on a tile $\overrightarrow{\vec{O}}$ with the broad spectrum AHG and saline.

Five sera containing both IgG and IgM anti-A were titrated in this manner and incubated for 10, 20, and 30 minutes. The results were compared with the standard two-stage technique (Table 3). The AHG titre was almost the same throughout but the saline (IgM) titre showed a fall in score with time so that at 30 minutes in the one-stage technique the results with both AHG and saline were comparable with the standard two-stage method. In most sera tested by either technique some residual saline agglutination $\frac{7}{0}$ activity remained that was not inactivated by further treatment with DTT and was probably due to IgG $N$ antibodies. This residual activity occurred in dilu- $N$ tions of 1 in 8 or less so that the one-stage technique was modified slightly, the initial dilution being 1 in $8 \mathrm{~W}$ in 0.01 M DTT then the doubling dilutions made in saline as above. Twenty samples containing high $\stackrel{\circ}{\subset}$ titre IgG anti-A were tested by both the one- and the two-stage methods. Nineteen of these gave unequi- ? vocal and almost identical titres by the one-stage and two-stage techniques (for an example see Table 4). $\frac{\vec{D}}{\mathrm{D}}$ Only one gave results that were not comparable $\frac{\rho}{\Phi}$ (Table 5). In this sample the two-stage technique gave titres with both saline and AHG of 1 in 32 and the one-stage technique gave titres with both of 1 in cells

\begin{tabular}{lll}
\hline & $\begin{array}{l}\text { Anti-D } \\
\text { titre }\end{array}$ & Score \\
\hline Before DTT treatment & 1 in 64 & 38 \\
After DTT treatment without dialysis & 1 in 16 & 18 \\
After DTT treatment with overnight dialysis & 1 in 64 & 36 \\
\hline
\end{tabular}

Table 1 Scoring for haemagglutination

by both the $2 \mathrm{ME}$ and the standard DTT technique. After incubation with the sulphydryl compound the sera were titrated against $A_{1}$ cells and incubated at $37^{\circ} \mathrm{C}$ for one hour, washed four times in saline, and tested on a tile with the broad spectrum AHG. No significant difference in titre was noticed by either technique. The 0.01 M DTT was also tested with known IgG and IgM antibodies. No IgM antibody tion time on the titre. DTT was shown to abolish the IgM antibody activity within 10 minutes whereas second batch of DTT and the results have been

The quick rate of inactivation of IgM antibodies stage technique encouraged the development of a stage 'all-in' technique as a rapid titration method for $G$ anti-A/B for use in clinical practice. Initially fou volumes of serum and four volumes of $0.01 \mathrm{M}$ DTT

Table 2 Effect of DTT on enzyme-premodified red blood 
Table 3 One-stage method. Effect of time of incubation on AHG titre compared with two-stage method

\begin{tabular}{|c|c|c|c|c|c|c|c|c|}
\hline & \multicolumn{7}{|c|}{ Titre } & \multirow[t]{2}{*}{ Score } \\
\hline & 2 & 4 & 8 & 16 & 32 & 64 & 128 & \\
\hline \multicolumn{9}{|l|}{ One-stage DTT } \\
\hline \multirow{2}{*}{$10 \mathrm{~min}$} & 8 & 5 & 3 & 2 & 0 & & & 18 \\
\hline & 10 & 10 & 8 & 5 & 3 & 2 & 0 & 38 \\
\hline \multirow{2}{*}{$20 \mathrm{~min}$} & 8 & 3 & 2 & 0 & & & 0 & 13 \\
\hline & 10 & 10 & 8 & 5 & 3 & 2 & $\mathbf{0}$ & 38 \\
\hline \multirow{2}{*}{$30 \mathrm{~min}\left\{\begin{array}{l}\text { Saline } \\
\text { AHG }\end{array}\right.$} & 5 & 3 & 0 & & & & & 8 \\
\hline & 10 & 10 & 8 & 5 & 3 & 2 & $\mathbf{0}$ & 38 \\
\hline \multicolumn{9}{|l|}{ Two-stage DTT } \\
\hline Saline & 5 & 3 & 0 & & & & & 8 \\
\hline AHG & 10 & 10 & 8 & 5 & 3 & 2 & 0 & 38 \\
\hline
\end{tabular}

Table 4 Effect of DTT treatment by one- and two-stage techniques on a high titre anti-A containing both IgM and Ig $G$ anti-A

\begin{tabular}{|c|c|c|c|c|c|c|c|c|c|}
\hline & \multicolumn{8}{|c|}{ Titre } & \multirow[t]{2}{*}{ Score } \\
\hline & 8 & 16 & 32 & 64 & 128 & 256 & 512 & 1024 & \\
\hline $\begin{array}{l}\text { Saline RT } \\
\text { One-stage DTT }\end{array}$ & 10 & 10 & 8 & 8 & 5 & 5 & 3 & 0 & 49 \\
\hline $\begin{array}{l}\text { AHG } \\
\text { Saline }\end{array}$ & $\begin{array}{r}10 \\
3\end{array}$ & $\begin{array}{r}10 \\
0\end{array}$ & $\begin{array}{l}8 \\
0\end{array}$ & 8 & 5 & 3 & 2 & 0 & $\begin{array}{r}46 \\
3\end{array}$ \\
\hline $\begin{array}{l}\text { Two-stage DTT } \\
\text { AHG } \\
\text { Saline }\end{array}$ & $\begin{array}{r}10 \\
3\end{array}$ & $\begin{array}{r}10 \\
0\end{array}$ & $\begin{array}{l}8 \\
0\end{array}$ & 8 & 5 & 5 & 3 & 0 & $\begin{array}{r}49 \\
3\end{array}$ \\
\hline
\end{tabular}

Table 5 Single sample showing anomalous results with one-stage method

\begin{tabular}{|c|c|c|c|c|c|c|c|c|c|c|}
\hline & \multicolumn{10}{|c|}{ Titre } \\
\hline & 2 & 4 & 8 & 16 & 32 & 64 & 128 & 256 & 512 & 1024 \\
\hline $\begin{array}{l}\text { Saline agglutination } \\
\text { One-stage DTT }\end{array}$ & 10 & 10 & 10 & 8 & 8 & 8 & 5 & 5 & 3 & 2 \\
\hline $\begin{array}{l}\text { Saline } \\
\text { AHG }\end{array}$ & & & $\begin{array}{l}8 \\
8\end{array}$ & $\begin{array}{l}8 \\
8\end{array}$ & $\begin{array}{l}5 \\
5\end{array}$ & $\begin{array}{l}3 \\
3\end{array}$ & $\begin{array}{l}2 \\
2\end{array}$ & $\begin{array}{l}\mathbf{0} \\
\mathbf{0}\end{array}$ & & \\
\hline $\begin{array}{l}\text { Two-stage DTT } \\
\text { Saline } \\
\text { AHG }\end{array}$ & $\begin{array}{l}8 \\
8\end{array}$ & $\begin{array}{l}5 \\
5\end{array}$ & $\begin{array}{l}5 \\
5\end{array}$ & $\begin{array}{l}3 \\
3\end{array}$ & 2 & $\begin{array}{l}\mathbf{0} \\
\mathbf{0}\end{array}$ & & & & \\
\hline
\end{tabular}

128. Insufficient serum was available to investigate this serum further, but in more than 100 samples that have been tested since by the one-stage method no other sera have been found that gave the same titre with both saline and AHG.

The sera used for the above studies were all selected because they haemolysed $A_{1} B$ cells at $37^{\circ} \mathrm{C}$, but after treatment with DTT no haemolysis was detected. Investigations using a group $\mathbf{O}$ 'cord' serum from an infant of a group $O$ mother with an IgG anti-A titre of 1 in 512 by AHG showed that before inactivation with DTT the serum haemolysed $A_{1}$ cells to a titre of 1 in 4 and agglutinated in saline at $20^{\circ} \mathrm{C}$ to a titre of 1 in 128 (Table 6). After inactivation the serum no longer haemolysed the $A_{1}$ cells but the saline agglutination titre remained unchanged at 1 in 128. The agglutination after DTT treatment was presumably due to the presence of maternal IgG anti-A.

This case suggests that the DTT prevented haemolysis by its action on one or more of the complement components and not by its effect on antibody molecules. Although the cells are not haemolysed complement components can be demonstrated on red cell suface when using many DTT inactivated sera containing high titres of IgG anti-A/B. These sera may give a higher titre when using a broad spectrum AHG, anti-IgG plus anti-complement, than when using a pure anti-IgG (Table 7). The difference is not usually more than one tube in a 
Table 6 Loss of haemolytic activity in cord serum after DTT treatment (infant group $O$, mother group $O$ )

\begin{tabular}{|c|c|c|c|c|c|c|c|c|c|c|}
\hline & \multicolumn{10}{|l|}{ Titre } \\
\hline & 2 & 4 & 8 & 16 & 32 & 64 & 128 & 256 & 512 & 1024 \\
\hline \multicolumn{11}{|l|}{ Untreated } \\
\hline Haemolysis & ++ & + & - & & & & & & & \\
\hline Agglutination & 10 & 10 & 10 & 8 & 8 & 5 & 3 & 0 & & \\
\hline \multicolumn{11}{|l|}{ Treated with DTT } \\
\hline Haemolvsis & - & - & & & & & & & & \\
\hline Agglutination & 10 & 10 & 10 & 8 & 8 & 5 & 3 & 0 & & \\
\hline AHG & & & & 10 & 10 & 8 & 5 & 5 & 3 & 0 \\
\hline
\end{tabular}

Table 7 One-and two-stage tests showing effect of complement components on AHG titre

\begin{tabular}{|c|c|c|c|c|c|c|c|c|}
\hline & \multicolumn{7}{|c|}{ Titre } & \multirow[t]{2}{*}{ Score } \\
\hline & 8 & 16 & 32 & 64 & 128 & 256 & 512 & \\
\hline \multicolumn{9}{|l|}{ One-stage DTT } \\
\hline BS AHG & 10 & 10 & 8 & 8 & 5 & 3 & 2 & 46 \\
\hline Anti-IgG & 8 & 8 & 5 & 5 & 3 & 2 & 0 & 31 \\
\hline Anti-complement & 5 & 3 & 2 & 0 & & & & 10 \\
\hline \multicolumn{9}{|l|}{ Two-stage DTT } \\
\hline BS AHG & 10 & 10 & 8 & 5 & 5 & 3 & 2 & 43 \\
\hline Anti-IgG & 8 & 8 & 5 & 5 & 3 & 2 & 0 & 31 \\
\hline Anti-complement & 2 & 0 & & & & & & 2 \\
\hline
\end{tabular}

Table 8 Titres obtained with the one-stage technique with 30 group $O$ sera that haemolysed $A_{1} B$ cells

\begin{tabular}{llllllllll}
\hline & \multicolumn{1}{l}{ Titre } & & & & & \\
\cline { 2 - 8 } & $<1$ in 8 & 1 in 8 & 1 in 16 & 1 in 32 & 1 in 64 & 1 in 128 & 1 in 256 & 1 in 512 \\
\hline No. & 5 & 3 & 2 & 5 & 9 & 2 & 3 & 1 \\
\hline
\end{tabular}

doubling dilution, but we now routinely use antiIgG and not broad spectrum AHG with the rapid one-stage technique. This anti-IgG, however, gives slightly weaker results, and hence lower scores, with IgG antibodies compared with the broad spectrum AHG. An IgG anti-D of titre 1 in 32 with both AHGs gives a score of 46 with the BS AHG and 34 with the anti-IgG.

Sera from 203 antenatal patients, of whom 100 were group $\mathrm{O}$, were tested for the presence of haemolysins with $A_{1} B$ cells at $37^{\circ} \mathrm{C}$. Of the group $O$ sera 32 showed haemolysis and 30 of these were titrated by the one-stage technique (Table 8). The highest titre obtained was 1 in 512, nine gave titres of 1 in 64, and five titres of less than 1 in $8: 50 \%$ had titres of 1 in 32 or less. No gelling occurred with any of the sera tested in this or any other series of tests, but most had normal immunoglobulin levels.

\section{Discussion}

ABO incompatibility between mother and fetus when the mother is group $O$ with high titres of IgG
anti-A/B and the fetus $A_{1}$ or $B$ can result in the newborn suffering from haemolytic disease due to IgG antibodies that have crossed the placenta. Whereas many methods have been recommended for predicting $\mathrm{ABO}$ haemolytic disease of the newborn (HDN), many workers feel that, because antenatal tests do not predict the severity of the disease and only a small percentage of affected infants need active treatment, tests before delivery are not warranted (International Forum, 1971). The postnatal tests must show that the mother and infant are $\mathrm{ABO}$ ? incompatible, that the mother's serum contains high $\tilde{O}$ titres of IgG anti-A or anti-B, and, wherever possible, $\underset{\mathrm{E}}{ }$ that the incompatible antibody can be eluted from,the infant's red cells. Voak and Bowley (1969) suggest that a titre of 1 in 512 by a spin AHG technique after 2ME treatment is significant and in the absence $\stackrel{?}{+}$ of an eluate is good presumptive evidence of $A B O$ HDN. The 2ME titre is therefore a very useful test but $\bar{c}$ it is time-consuming and the reagent is odourous. DTT seems to be a reagent that offers a good alter- $\mathbb{\Phi}$ native to $2 \mathrm{ME}$ and, since there is no need to dialyse DTT-treated serum when using an AHG technique, 
it is less time-consuming-although when enzyme techniques are used dialysis overnight against saline seems to be essential.

Inactivation of an IgM anti-I with 0.01 M DTT was more rapid than with $0.1 \mathrm{M} 2 \mathrm{ME}$. Freedman et al. (1976) also showed that 0.01 M DTT was better in this respect than $0.1 \mathrm{M} 2 \mathrm{ME}$ but that 0.2 $M$ 2ME gave even better results. However, their tests with DTT seem to suggest a slower rate of IgM antibody inactivation than those reported here. In tests with two batches of DTT the results have been comparable but the quality of the reagents may vary and each batch should be carefully tested before being used. DTT when used in a two-stage technique with a 30 -minute inactivation period is less time-consuming than using $0 \cdot 1 \mathrm{M} 2 \mathrm{ME}$, but the much greater speed at which it inactivated an IgM anti-I led to the development of this simpler one-stage technique. The results show that for a titre of anti-A or anti-B it compared well with the two-stage technique although we had to use anti-IgG AHG as more complement is fixed to the cells than in the twostage technique. However, the difference in titre between the broad spectrum AHG and the antiIgG was never more than one tube.

It seems that the DTT affects the complement components in the serum since longer exposure to DTT in the two-stage method results in less complement on the cells. The components present on the cells after the one-stage test react with both anti-C3 and C4 (no other anti-sera were available), but since the cells are not lysed DTT probably inactivated later complement components. The cord serum tested contained IgG antibody of maternal origin and, while the titre was not affected by DTT, the serum after treatment did not lyse the $A_{1}$ cells again indicating the effect of DTT on complement components.

The use of $0.01 \mathrm{M}$ DTT has proved generally useful as a reagent in blood transfusion techniques and in particular in the one-stage technique for titrating
IgG anti-A/B in cases of suspected ABO HDN. Not enough cases have been studied using this technique to suggest a titre that would be considered to be significant, in the absence of an eluate from the infant's red cells, but it is possibly slightly less than the 1 in 256 reported by Voak and Bowley (1969). Three cases of group A infants suffering from ABO HDN but not requiring treatment have been investigated in which anti-A was eluted from their red cells and the maternal IgG titre was 1 in 64 using the onestage technique described here.

I thank Dr P. J. Kingston for his support and useful criticism of this work, and Mrs P. Fassioms for technical assistance.

\section{References}

Freedman, J., Masters, C. A., Newlands, M., and Mollison, P. L. (1976). Optimal conditions for the use of sulphydryl compounds in dissociating red cell antibodies. Vox Sanguinis, 30, 231-239.

International Forum (1971). What is the optimal serological analysis of haemolytic disease of the newborn due to ABO incompatibility? Vox Sanguinis, 20, 182192.

Olson, P. R., Weiblen, B. J., O’Leary, J. J., Moscowitz, A. J., and McCullough, J. (1976). A simple technique for the inactivation of IgM antibodies using Dithiothreitol. Vox Sanguinis, 30, 149-159.

Pirofsky, B., and Rosner, E. R. (1974). DTT test: a new method to differentiate IgM and IgG erythrocyte antibodies. Vox Sanguinis, 27, 480-488.

Reesink, H. W., Van der Hart, M., and Van Loghem, J. J. (1972). Evaluation of a simple method for determination of IgG titre anti-A or -B in cases of possible $\mathrm{ABO}$ blood group incompatability. Vox Sanguinis, 22, 397407.

Voak, D., and Bowley, C. C. (1969). A detailed serological study on the prediction and diagnosis of $\mathrm{ABO}$ haemolytic disease of the newborn. Vox Sanguinis, 17, 321-348. 